\title{
Empyema caused by foreign body aspiration
}

\author{
Mehrnaz Asadi Gharabaghi, ${ }^{1}$ Mehrnoush Asadi Gharabaghi, ${ }^{2}$ Shahram Firoozbakhsh ${ }^{1}$
}

${ }^{1}$ Department of Pulmonary Medicine, Tehran University of Medical Sciences, Tehran, Islamic Republic of Iran ${ }^{2}$ Department of Pharmacy, Maharashtra Institute of Pharmacy, Pune, Maharashtra, India

\section{Correspondence to} Dr Mehrnaz Asadi Gharabaghi, asadi_m@tums.ac.ir

\section{To cite:}

Asadi Gharabaghi M,

Asadi Gharabaghi M,

Firoozbakhsh S. BMJ Case Reports Published online:

17 December 2012

doi:10.1136/bcr-2012-

007760

\section{DESCRIPTION}

A 48-year-old man presented with a 2-week history of progressive dyspnoea and productive cough. $\mathrm{He}$ was an exsmoker and remembered recurrent bouts of hospitalisation due to pneumonia-like symptoms within the previous 4 years. He did not remember any aspiration event before that time. $\mathrm{He}$ was told to have localised right lower lobe bronchiectasis. Bronchoscopic exam of the airways revealed no evidence of stricture, tumour or foreign body at that time .He refused to undergo surgery.

On physical examination, fever, finger clubbing, diminished breath sounds and dullness over the lower region of right hemithorax were found.

Blood tests showed leucocytosis, thrombocytosis, normocytic normochromic anaemia, increased C reactive protein level and erythrocyte sedimentation rate.

There was right-sided pleural effusion on plain radiography of chest. Aspiration of frank pus on thoracentesis established diagnosis of empyema. CT scanning of the chest showed honeycombing bronchiectasis of posterobasal segment of right lower lobe and right-sided pleural effusion and pleural thickening (figure $1 \mathrm{~A}, \mathrm{~B}$ ).He received intravenous
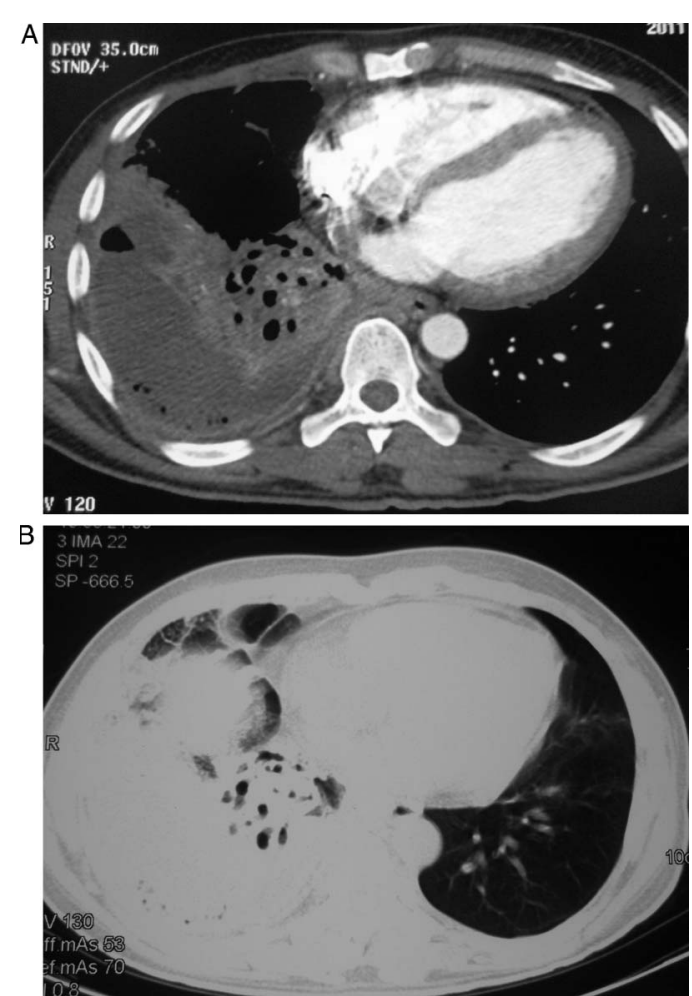

Figure 1 (A and B) Sections of CT scanning of chest illustrating pleural effusion, pleural thickening, iatrogenic pneumothorax and honeycombing bronchiectasis of posterior segment of right lower lobe.

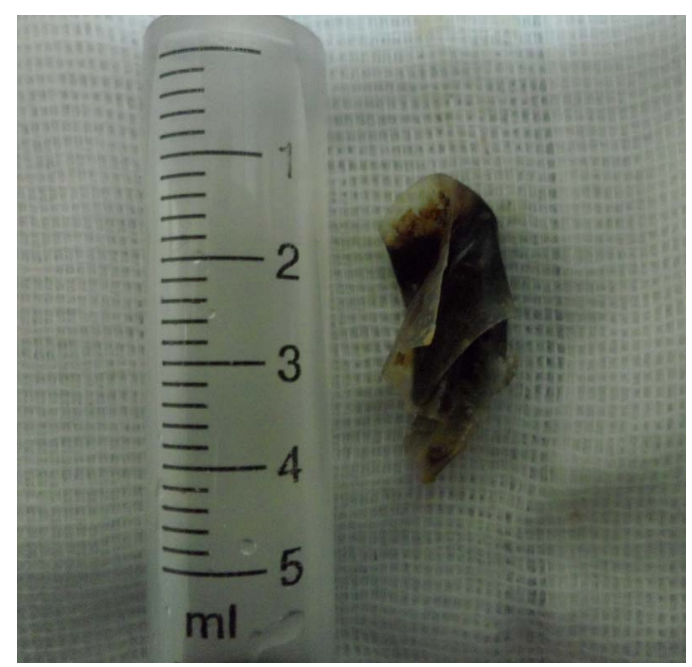

Figure 2 Extracted plastic foreign body from bronchial tree measuring $\sim 3 \times 1 \mathrm{~cm}$.

clindamycin and ceftriaxone and underwent tube thoracostomy. On fiberoptic bronchoscopy, a plastic foreign body measuring $\sim 3 \times 1 \mathrm{~cm}$ was removed from the lumen of posterobasal segment of right lower lobe (figure 2).

Unsuspected aspirated foreign body may be the cause of unresolved pneumonia or empyema in adult patient. Fiberoptic bronchoscopy is the treatment of choice in majority of patients but the rate of procedure-related complications will be increased by delay in diagnosis. Unresolved pneumonia, localised bronchiectasis or localised hyperlucency/ air trapping are helpful clinical clues. ${ }^{1}{ }^{2}$ Therefore, a high clinical suspicion is necessary for on-time diagnosis and uneventful treatment.

\section{Learning points}

- Foreign body aspiration should be considered as an uncommon cause of unresolved pneumonia, localised bronchiectasis or localised air trapping in adult patients even in the absence of history of aspiration.

- It is not uncommon for a long-term unrecognised foreign body aspiration to present with an empyema. 


\section{REFERENCES}

1 Zissin R, Shapiro-Feinberg M, Rozenman J, et al. CT findings of the chest in adults with aspirated foreign bodies. Eur Radiol 2001;11:606-11.
2 Dong YC, Zhou GW, Bai C, et al. Removal of tracheobronchial foreign bodies in adults using a flexible bronchoscope: experience with 200 cases in China. Intern Med 2012;51:2515-19.

Copyright 2012 BMJ Publishing Group. All rights reserved. For permission to reuse any of this content visit http://group.bmj.com/group/rights-licensing/permissions.

BMJ Case Report Fellows may re-use this article for personal use and teaching without any further permission.

Become a Fellow of BMJ Case Reports today and you can:

- Submit as many cases as you like

- Enjoy fast sympathetic peer review and rapid publication of accepted articles

- Access all the published articles

- Re-use any of the published material for personal use and teaching without further permission

For information on Institutional Fellowships contact consortiasales@bmjgroup.com

Visit casereports.bmj.com for more articles like this and to become a Fellow 